\title{
DEMOGRAPHIC TRANSITION \\ AT THE REGIONAL LEVEL IN CZECH LANDS
}

\section{Cristina AVRAM1, PhD, Charles University, Department of Demography and Geodemography, Czech Republic}

DOI: https://doi.org/10.36004/nier.es.2020.1-10

JEL Classification: J10, J13, J19, 015

UDC: 314 (437.3)

\section{ABSTRACT}

This study presents the results of the development of demographic transition at the regional level in the Czech Lands. The analysis uses data from censuses and vital statistics. The period for analysis is 1869-1935, and the data was recalculated for the 2011 administrative division. In the study, we used the classical approach of analysis of the demographic processes. This article aims, first, to show the evolution of mortality and fertility levels at the regional level during the demographic transition, and second, to show that the demographic transition in the Czech lands follows the patterns of other European countries, but with some particularities at the regional level.

Keywords: demographic transition, mortality, fertility, migration, Czechia.

In acest articol sunt prezentate rezultatele cercetării privind tranziția demografică la nivel regional în Cehia. Studiul se bazează pe datele de la recensămintele populației și statistica vitală. Perioada de analiză este 1869-1935, iar datele sunt recalculate pentru organizarea adminsitrativteritorială din 2011. În studiul au fost utilizate abordări clasice de analiză a proceselor demografice. Acest articol descrie evoluția mortalității și fertilității la nivel regional pe parcursul tranziției demografice și demonstrează că tranziția demografică în Cehia urmează un traseu similar cu alte țări europene, dar are anumite particularități la nivel regional.

Cuvinte-cheie: tranziție demografică, mortalitate, fertilitate, migrație, Cehia.

В данном исследовании представлены результаты развития демографического перехода на региональном уровне в чешских землях. В анализе используются данные переписей и статистики естественного движения населения. Период анализа составляет 1869-1935. Данные были пересчитаны для административного-территориальное деления 2011 года. В исследовании использовался классический подход анализа демографических процессов. В этой статье описана эволюция уровней смертности и рождаемости на региональном уровне во время демографического перехода, и показывает, что демографический переход в Чехии повторяет модели других европейских стран, но имеет некоторые особенности на региональном уровне.

Ключевые слова: демографический переход, смертность, рождаемость, миграция, Чехия.

\section{INTRODUCTION}

The demographic transition became "the central preoccupation of modern demography" (Demeny 1968), and is the shift from the slow growth of the population due to relatively high fertility and mortality to slow growth due to low fertility and mortality (Coale 1984:531). Moreover, demographic transition theory applied to the developing countries shows impressive regularities (Kirk 1996). In each example, mortality preceded fertility decline, resulting in accelerated population growth underestimated by some researchers. 
The duration of the demographic transition is different for each country or region, but the later it emerges, the faster the pace and dynamics of the process (Pavlík 1977). In Northern Europe, the demographic transition lasted 75-100 years, in Eastern Europe - 20-25 years, and lasts even less for less developed countries that are still in the process (Preston 1975).

\section{LITERATURE REVIEW AND GAP POSITIONING}

According to some studies (Pavlík, Rychtaříková, and Šubrtová 1986:568), the demographic transition in the Czech Lands started approximately in 1830. At the beginning of the $19^{\text {th }}$ century, the crude death rates were about 25 per thousand people, and life expectancy was about 33 years (Pavlík 1964). In the 1900s, there was a dramatic decrease in mortality, life expectancy reaching approximately 40 years, and continuously increased until 56 years at the end of demographic transition (Arltová, Langhamrová and Langhamrová 2013). In the first phase of demographic transition, the crude birth rate was 45 per thousand people. Some research shows that the earliest fertility decline in the Czech Lands was registered in Bohemia, specifically in Prague and Liberec region (Pavlík, Kučera and Hampl 1994:34). And from these regions, it spread throughout the country (Demeny 1968). Because of data availability, this analysis began in 1869, with the first modern census conducted in Austria-Hungary, and it ended in 1937, with the last available comparable data before the WWII, but also this is the time when the demographic transition has finished in the Czech lands.

The interest in regional demographic transition appeared later (e.g., Leasure 1963; Coale 1986; Fialová, Pavlík and Vereš 1990; Fialová 1991; Diebolt and Perrin 2017), and it wasn't researched in-depth and its correlations with ageing, including for Czechia. The main aim of this study is to contribute to understanding the determinants and evolution of demographic tran sition, specifically mortality and fertility decline, at the regional level in the Czech lands. The research on the demographic transition at the regional level will explain the current demographic situation from its roots because the comprehensive knowledge of the past is the prerequisite for an adequate explanation of present phenomena. Moreover, the analysis of the particularities of the development of demographic transition at the regional level can explain and predict the time and pace of ageing at the regional level.

The following hypotheses are tested in this article:

1. Demographic transition in the Czech lands followed, in general, the pattern of other European countries.

2. Demographic transition in the Czech lands started in the Northern industrialized districts and Prague, the capital, and then it diffused to the peripheries.

3. There is a close link in the fertility and mortality decline of the population located in the same geographical region.

\section{THE THEORETICAL FRAMEWORK OF THE STUDY}

The research is based first of all on the demographic transition theory. The theory of demographic transition attempts to explain the changes in mortality, fertility, and age structure. One of the most common definitions of demographic transition is the transition from a regime of (moderately) high birth and death rates (at approximate balance) to very low levels of fertility and mortality (also at approximate balance) (Knodel 1974; Coale 1986). Other standard definitions are: the demographic transition is the process of change from the primitive type of reproduction to the modern type of reproduction (Visnevski 1976; Pavlik 1980), the shift from the nonparity-related restriction of fertility to parity-related restriction of fertility (Coale 1986) or the shift from unplanned parenthood to family planning.

For a deeper understanding of the mortality and fertility decline, additional theories were applied. The epidemiological transition theory (Omran 1998:102) explains the mortality decline by using four stages (specific for western transitions). In the first stage - "pestilence and famine", these being the leading causes of death, and it was specific for the pre-transition societies, and most deaths were occurring before the age of 40 (Harper 2016). The second stage - "receding pandemics", mortality caused by infectious diseases were decreasing, especially child mortality, life expectancy reached 50 (Harper 2016). In the third stage - "the age of degenerative, stress and manmade diseases" people survive to their 70s and over (Harper 2016). The fourth stage - "age of 
declining cardiovascular mortality, ageing etc.", the degenerative diseases are delayed, and more time is spent with chronic disease or disability. Moreover, life expectancy at older ages is still increasing (Harper 2016).

For explaining the determinants of fertility decline, several theories were applied: the intergenerational wealth flows theory of fertility decline (Caldwell 1976), the economic theory of fertility decline (Schultz 1974; Becker 1981), the diffusion of innovations theory (Cleland and Wilson 1987), the cultural and ideational theory (Lesthaeghe 1983), theory of multi-phasic demographic response (Davis 1963) and second demographic transition.

Theory of multi-phasic demographic response (Davis 1963) explains that the out-migration has the role of relieving the pressure of population growth. As a result, the fertility decline in rural areas was delayed. The population from rural areas was the primary source of urban growth during demographic transition.

\section{DATA AND METHODS}

Each significant change of political and social situation brought reforms to the territorialadministrative division. Moreover, the changes in the administrative division had an impact on the development of the statistics; this is why it is important to follow its development, and also the reforms in administrative divisions are the main obstacle in having comparable time-series for a more extended period.

In this study, historical data were recalculated to the current district level (2011 administrative division). The recalculation was necessary due to the four major administrative reforms were implemented on the territory of the Czech Republic between 1850 and nowadays. The data were recalculated by defining ratio of each political district /judicial district/district area (1869-2001) in actual districts (LAU1) areas from 2011 (based on ArcČR 3.3 shapefiles). The ratios were calculated by using spatial overlay. Calculated proportions of political districts were used to recalculate the rest of the data. CZSO (Růžková and Škrabal 2006) has recalculated only total number of population on the actual districts for the period 1869-2011. These data are available for download on CZSO public database website and they were downloaded at level of municipality parts ("části obce") for cross-checking (finding errors in data and calculations), for more precise political districts administrative borders reconstruction and recreation of more precise historical maps.

The main data sources for the research are the following:

1. Censuses $(1869,1880,1890,1900,1910,1921,1930)$.

2. Vital statistics $(1868,1872-1937)$.

The data collected for the research are predominantly at the district level (1831-1847 regions, 1868-1913 - political districts, 1919-1937 - judicial districts).

Crude death rates, crude birth rates, and net migration rates are mapped for recalculated data at the district level (LAU1).

QGIS3 open-source Geographical information system software was used for 1869-1910 maps reconstruction, editing, analysis, and all spatial overlay operations.

\section{MAIN RESULTS}

Evolution of mortality

The geographical distribution helps us to create a more complete and accurate explanation of the demographic changes. In this section, we present the evolution of crude death rates for the period 1869-1937 at the regional level.

During the pre-transition period, the death and birth rates were high (or moderately high). In the first phase of demographic transition, death rates started to fall continuously until the end of transition when death rates stabilized around 10-15 per thousand people.

For 1869, crude death rates were ranging between 22 and over 30 per thousand people (figure 1). Most of the districts were in the range of 25 to 30 per thousand people, which is considered a pre-decline level of mortality (Reher 2004). Some of the districts had a high crude death rate of over 30 per thousand people, and several districts entered the mortality decline phase with a crude death rate under 25 per thousand people (Reher 2004). 


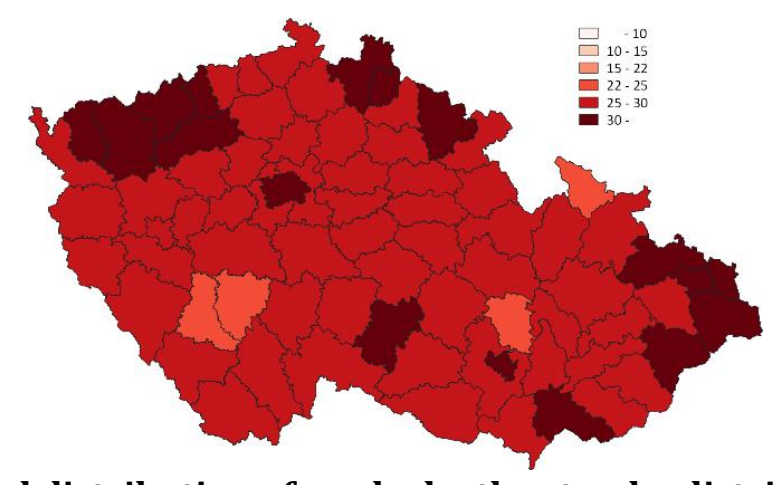

Figure 1. Geographical distribution of crude death rates, by districts, Czech lands, 1869 Note: only the civil population in the total population was included.

Sources: Author's calculations based on data from Austrian Statistics, CZSO and Historický GIS.

Figure 2, compared to figure 1, shows that mortality was still fluctuating. No significant changes occurred between 1869 and 1881. The high number of deaths is predominant in several districts from Northern and Central Bohemia and South-Western Moravia. Mortality remained high in Prague at 36 per thousand people. The change between in mortality between 1869 and 1880 showed a variance of $4 \%$ on average. The highest increase accounted for 32\% for Kroměřǐž and Zlín, and 27\% for Uherské Hradiště. The highest decrease accounted for $13 \%$ for České Budějovice, and $10 \%$ for Brno-město and Sokolov.

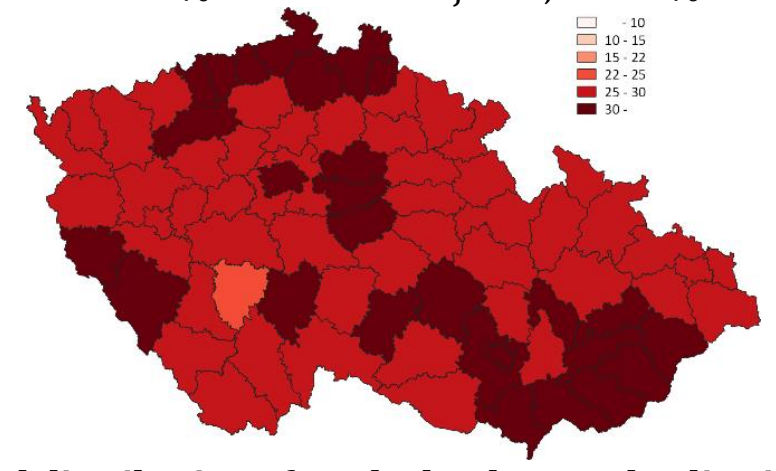

Figure 2. Geographical distribution of crude death rates, by districts, Czech lands, 1881 Sources: Author's calculations based on data from Austrian Statistics, CZSO and Historický GIS.

From 1881 to 1890 , several districts entered the demographic transition, according to the definition of Reher (2004), where the level of crude death rates dropped under 25 per thousand people (figure 3). The districts with the lowest mortality were mostly located in Western Bohemia and a few in Central Bohemia. The mortality was still high for Prague and accounted between 30 and 35 per thousand people, but also in other cities, e.g., Liberec, Brno, Kroměř́žz, Jihlava. During this period, death rates were mostly decreasing, on average, by $-1.5 \%$. The highest decrease was observed in Prague-východ by $-29 \%$, in Prague by $-17 \%$ and in Kroměříž by $-17 \%$. The highest increase was in Blansko, Svitavy, Sokolov, Bruntál, and Frýdek-Místek, and accounted for about 10\%.

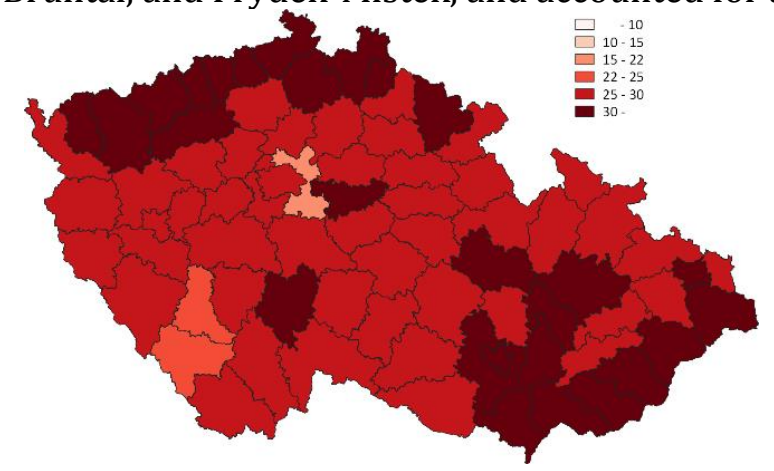

Figure 3. Geographical distribution of crude death rates, by districts, Czech lands, 1890 Sources: Author's calculations based on data from Austrian Statistics, CZSO and Historický GIS. 
Mortality was declining gradually until 1890 . Crude death rates changed radically from 1890 to 1900 , as seen from the comparison of figure 3 and figure 4. In 1900 only five political districts had a crude death rate higher than 30 per thousand people. In the recalculated map, all districts had a crude death rate of under 30 per thousand people. Mortality was quite heterogeneous during this period, ranging between 15 and over 30 per thousand people. The change in mortality accounted for $-16 \%$ on average within a range from $-38 \%$ to $-2 \%$. The crude death rate is decreasing in all the districts. The highest decrease was in Teplice, Prague-západ, and Plzeň-město. The lowest decrease was in Jeseník, Semily and Prague-východ.

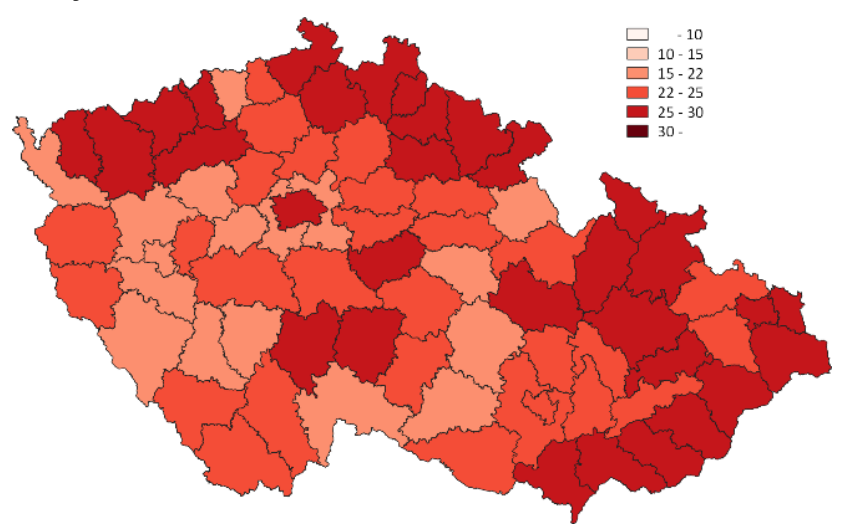

Figure 4. Geographical distribution of crude death rates, by districts, Czech lands, 1900 Sources: Author's calculations based on data from Austrian Statistics, CZSO, and Historický GIS.

In sharp contrast with the 1900 situation, figure 5 shows that in 1910, mortality decreased substantially in almost all districts. The homogeneity among districts increased considerably. Mortality levels were high in Prague and Brno, in the range of 25 and 30 per thousand people, although it decreased from 1900 levels (figure 5). Some districts located in Eastern Moravia and Silesia had higher mortality also - between 22 and 25 per thousand people. For this period, the most significant change in mortality across the districts was observed. The difference accounted on average for $-19 \%$. The highest decrease accounted for 35\% in Vsetín and Pelhřimov, and the lowest drop accounted for $1 \%$ in Rychnov nad Kněžnou.

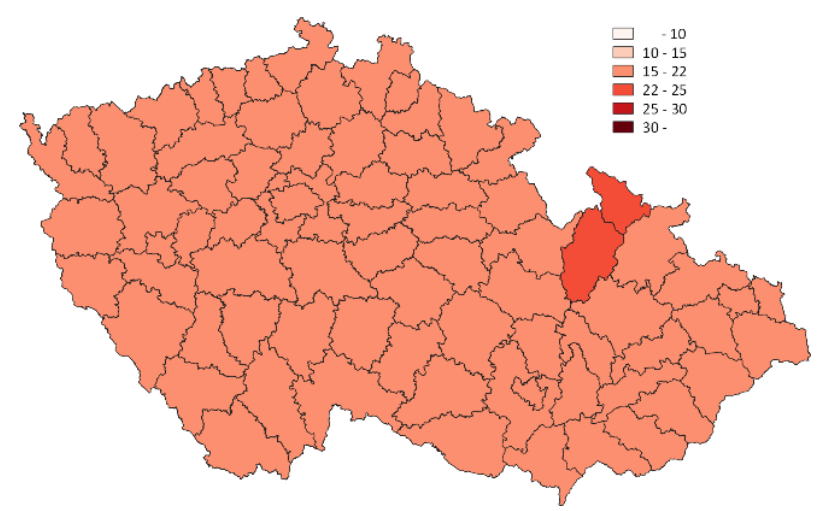

Figure. 5 Geographical distribution of crude death rates, by districts, Czech lands, 1910 Sources: Author's calculations based on data from Austrian Statistics, CZSO, and Historický GIS.

Crude death rate continued to decrease after 1910. In 1921, in several districts in Central Bohemia and several districts from periphery areas, crude death rates reached 10-15 per thousand people (figure 6). The mortality in Prague and other cities finally reached mortality levels similar to the national average - 15 to 22 per thousand people. The change between 1910 and 1921 accounted for about $-16 \%$. Mortality continued to decline in this period. The highest decrease accounted for about 30\% in Prague and Ostrava-město. 


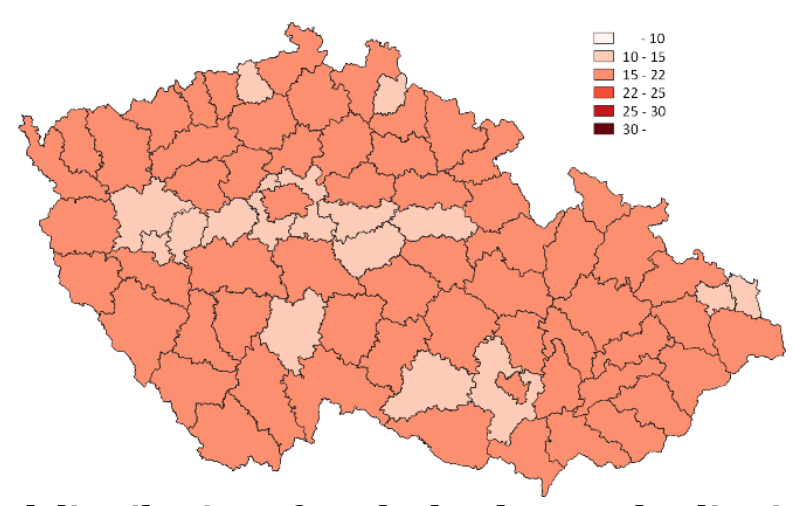

Figure 6. Geographical distribution of crude death rates, by districts, Czech lands, 1921 Sources: Author's calculations based on data from Austrian Statistics, CZSO and Historický GIS.

A substantial reduction in crude death rates occurred between 1921 and 1930. In most districts, the crude death rate ranged between 10 and 15 per thousand people (figure 7). The change in mortality accounted for $-14 \%$ on average. The highest decrease accounted for about $37 \%$ in Brnoměsto and about $28 \%$ in Prague, Sokolov, and Frýdek-Místek.

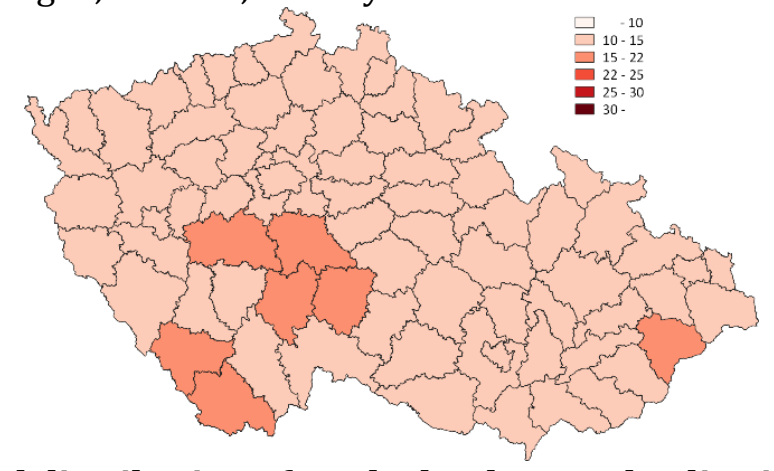

Figure 7. Geographical distribution of crude death rates, by districts, Czech lands, 1930 Sources: Author's calculations based on data from Austrian Statistics, CZSO, and Historický GIS.

Mortality continues to decline, and at the end of demographic transition, the average crude death rate was between 10 and 15 per thousand people and quite homogeneous across districts. Approximately ten judicial districts reached a crude death rate of 10 or less per thousand people. The mortality levels were stabilizing. The lowest value of the crude death rate was for Ostrava-město with 9.7 per thousand people. The highest crude death rate was in Prachatice and Strakonice and accounted for 16 per thousand people. The districts with the highest crude death rate ranging between 15 and 22 were: Př́bram, Benešov, Strakonice, Prachatice, Tábor and Jindřichův Hradec. The change in mortality between 1930 and 1937 accounted for about $-5 \%$. The highest decrease accounted for about 16\% in Prague-západ, Chomutov, Hodonín, and Zlín. The mortality continued to fall, but not as sharp as in the previous periods.

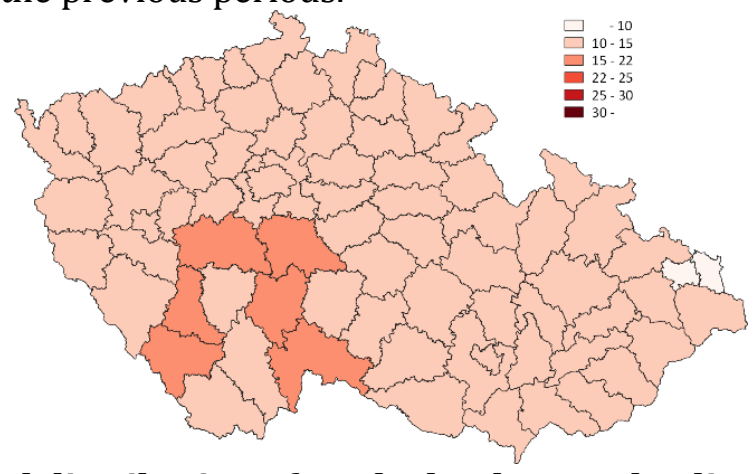

Figure 8. Geographical distribution of crude death rates, by districts, Czech lands, 1937 Sources: Author's calculations based on data from Austrian Statistics, CZSO, and Historický GIS. 
Mortality transition varied across the districts. The mortality decline seems to have started earlier than in 1869 in some districts. The highest crude death rate was observed in several districts in Northern Bohemia, Central Bohemia and South-Western Moravia. The mortality decline started to "spread" to more districts in Western and Central Bohemia between 1881 and 1890. Between 1890 and 1900, mortality declined in all districts, but it remained heterogeneous, ranging from 15 to over 30 per thousand people. Between 1900 and 1910, crude death rates decreased significantly, and for the first time, a homogeneity in mortality is observed. Crude death rates range between 15 and 22 per thousand people, except few districts in Eastern Moravia and Silesia (22-25 per thousand people) and Prague and Brno (25 and 30 per thousand people). After 1930 the crude death rate declines at a slower pace compared to the previous period. The decrease continues, and by the end of demographic transition, the districts reach a crude death rate ranging between 10 and 15 per thousand. Only in a few it decreases under 10 per thousand people. During the demographic transition, the mortality in Czech lands decreased by approximately $50 \%$ in all districts.

Evolution of fertility

In this section, we present the evolution of the crude birth rate for the period 1869 to 1937 . Similarly to mortality analysis, the crude birth rates are shown on maps for eight years: 1881,1890 , $1900,1910,1921,1930$, and 1937. In the third stage of demographic transition (according to Rowland 2003), fertility started to fall gradually. The natality varied across the districts in 1869 (figure 9). Most of the crude birth rates show pre-transitional values. The crude birth rate was ranging from 30 to over 40 per thousand people. A crude birth rate of 40 per thousand people is considered a pre-transition level of fertility or natural fertility (Henry 1961), this being considered moderately high fertility (Coale 1986; Diebolt and Perrin 2017). Moreover, a crude birth rate of 35 per thousand people is considered as the start of fertility decline by some researchers (Chesnais 1992).

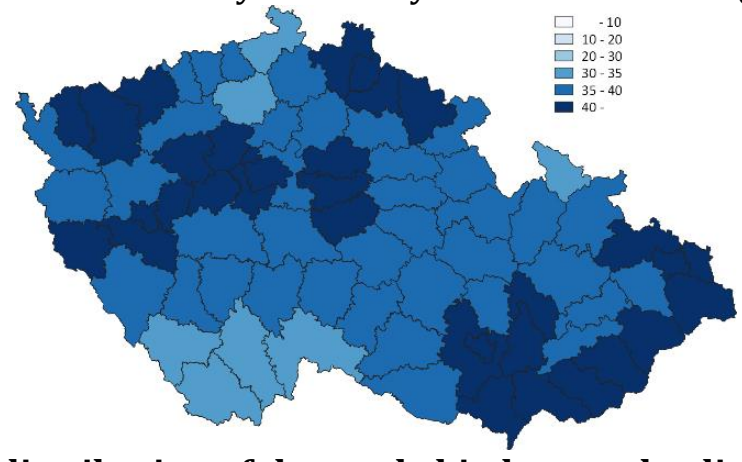

Figure 9. Geographical distribution of the crude birth rates, by districts, Czech lands, 1869 Note: only the civil population in the total population is included. Sources: Author's calculations based on data from Austrian Statistics, CZSO and Historický GIS.

Although the situation in 1881 (figure 10) was similar to the one in 1869, we can see that Northern Bohemia, including the city of Liberec, Southern Bohemia, Silesia and Northern Moravia entered the phase of fertility decline with a crude birth rate under 35 per thousand people (Diebolt and Perrin 2017).

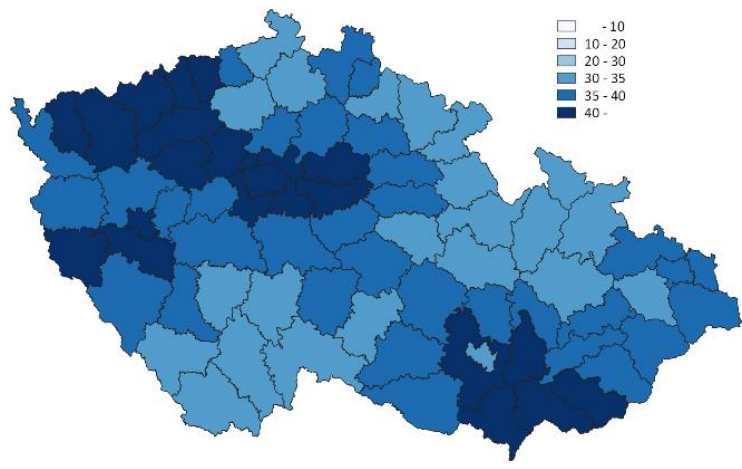

Figure 10. Geographical distribution of crude birth rates, by districts, Czech lands, 1881 Sources: Author's calculations based on data from Austrian Statistics, CZSO and Historický GIS. 
The change between recalculated districts in 1869 and 1880 accounted for $-2 \%$ on average. The most considerable change was in Brno-město and accounted for $-10 \%$. In general, the crude birth rate decreased from 44 to 34 per thousand people (figure 10).

After 1881, fertility continues to decline. Just a few districts had a crude birth rate higher than 40 per thousand people: Sokolov, Most, Teplice, Ústí nad Labem in the Northern Bohemia and FrýdekMístek, Ostrava-město, Karviná in Silesia (figure 11). We observe that the crude birth rate dropped under 35 per thousand people in most districts in the Central Bohemia, including Prague, marking the beginning of the fertility decline phase. Districts that are still in the pre-decline phase (35 to 40 per thousand) were mostly located in the West-North part of Bohemia, South-West of Moravia, and some districts in Silesia. There was heterogeneity among districts at this stage. The overall change between 1881 and 1890 accounted for approximately $-5 \%$. The crude birth rate declined the most in Praguevýchod by 35\% and increased the most in Frýdek-Místek and Karviná by almost 14\%.

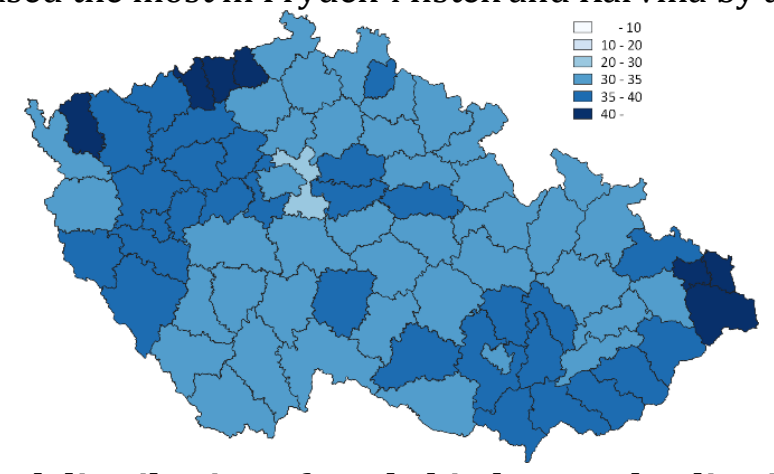

Figure 11. Geographical distribution of crude birth rates, by districts, Czech lands, 1890 Sources: Author's calculations based on data from Austrian Statistics, CZSO and Historický GIS.

After 1890 the crude birth rate continued to decline under 35 per thousand people in Western and Central Bohemia. Still, it seemed to stagnate in Southern and Eastern Moravia and some districts in Western Moravia and even increasing in some districts (figure 12). The overall change between 1890 and 1900 accounted for approximately $+0.3 \%$. The highest decline in natality was recorded in Prague-západ by $23 \%$, and the highest increase was recorded for Ostrava-město and Prague-východ by $17 \%$.

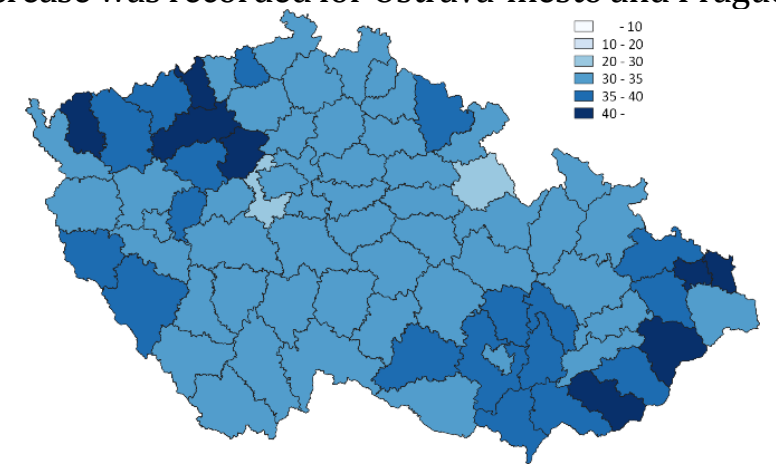

Figure 12. Geographical distribution of the crude birth rates, by districts, Czech lands, 1900 Sources: Author's calculations based on data from Austrian Statistics, CZSO and Historický GIS.

A substantial reduction in natality was observed between 1900 and 1910. In 10 years, most districts moved to a modern regime of controlled fertility with a crude birth rate of 30 per thousand people (Chesnais 1992) (figure 13). Despite the general trend, Moravia and Southern Silesia had a high crude birth rate, between 30 and 35 per thousand people, some over 35 per thousand people. Also, several districts in Western (Sokolov, Domažlice, Klatovy), Northern (Chomutov, Most, Teplice), and Central Bohemia (Rakovník, Kladno, Beroun) recorded high crude birth rates between 30-35 or over 35 per thousand people. The average change between 1900 and 1910 accounted for approximately $-17 \%$. The decline was universal, except one district - Rychnov nad Kněžnou, where the crude birth rate increased by $3 \%$. 


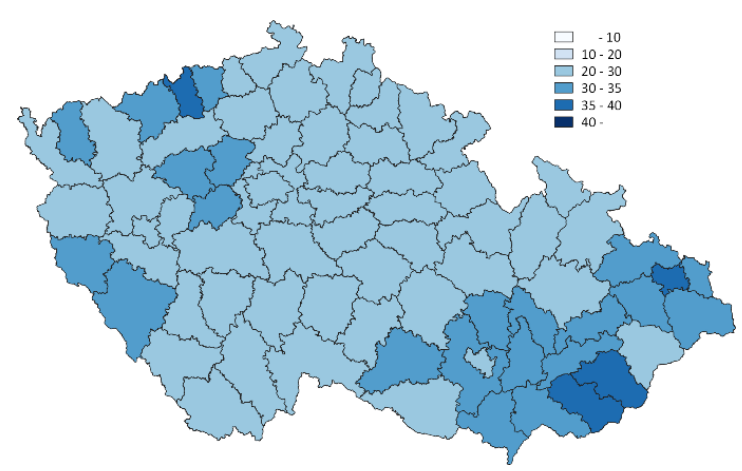

Figure 13. Geographical distribution of the crude birth rates, by districts, Czech lands, 1910 Sources: Author's calculations based on data from Austrian Statistics, CZSO and Historický GIS.

After 1910 fertility continues to decline. A convergence of the crude birth rate under 30 per thousand people was observed (figure 14). The modern regime of controlled fertility (crude birth rate 30 per thousand people) was spread almost all over the Czech lands, with some exceptions at the peripheries, especially in Moravia and Silesia. Prague and Liberec had one of the lowest crude birth rates ranging between 10 and 20 per thousand people. The average change between 1910 and 1921 accounted for approximately $-11 \%$. The highest decrease of approximately $25 \%$ was recorded in Prague, Plzeň-město, Náchod and Pardubice. The highest increase of $20 \%$ was recorded in Vsetín.

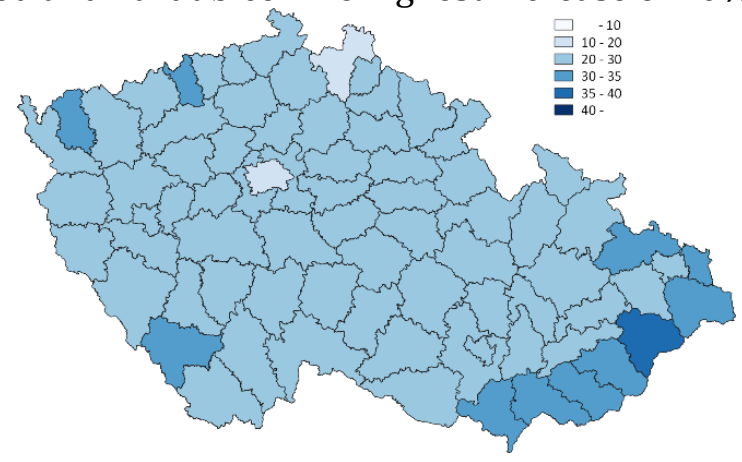

Figure 14. Geographical distribution of the crude birth rates, by districts, Czech lands, 1921 Sources: Author's calculations based on data from Austrian Statistics, CZSO and Historický GIS.

There was a sharp drop in fertility between the years 1921 and 1930 - fertility declined in about half of the districts (figure 15). The North-Eastern Bohemia, several districts in South and Central Bohemia, and several in Moravia, including Brno, recorded the lowest values for crude birth rate ranging between 10 and 20 per thousand people. Moreover, a crude birth rate under 20 means that most of the women use parity limitation of fertility (Diebolt and Perrin 2017). The average change between 1921 and 1930 accounted for approximately $-22 \%$, one of the highest changes recorded during the demographic transition. The decline was universal. The sharpest drop accounted for $48 \%$ in Brno-město, and the smallest drop accounted for $1 \%$ in Prague-východ.

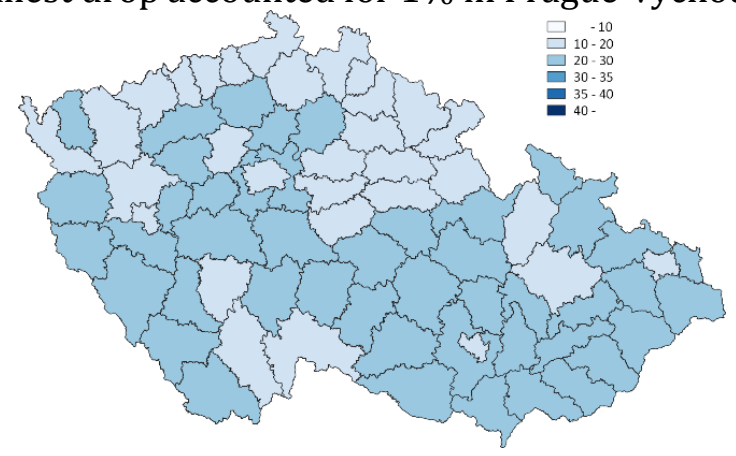

Figure 15. Geographical distribution of the crude birth rates, by districts, Czech lands, 1930 Sources: Author's calculations based on data from Austrian Statistics, CZSO and Historický GIS. 
After 1930 the decline of fertility continued. Crude birth rate was between 10 and 20 per thousand people in almost all the districts. There was a very high level of homogeneity among the districts (figure 16). The lowest crude birth rate of under 10 per thousand people was reached in two districts: Liberec and Jablonec nad Nisou. Districts with the highest crude birth rate (between 20 and 30 per thousand people) were located at the peripheries: Prachatice, Český Krumlov in Bohemia and Vsetín, Zlín, Uherské Hradiště in Moravia. Surprisingly, the average change between 1930 and 1937 accounts for approximately $-26 \%$, which was the highest change recorded during the demographic transition. The sharpest drop was about 43\% in Karviná and Prague-západ, and the smallest decline was about $10 \%$ in Písek and Brno-město.

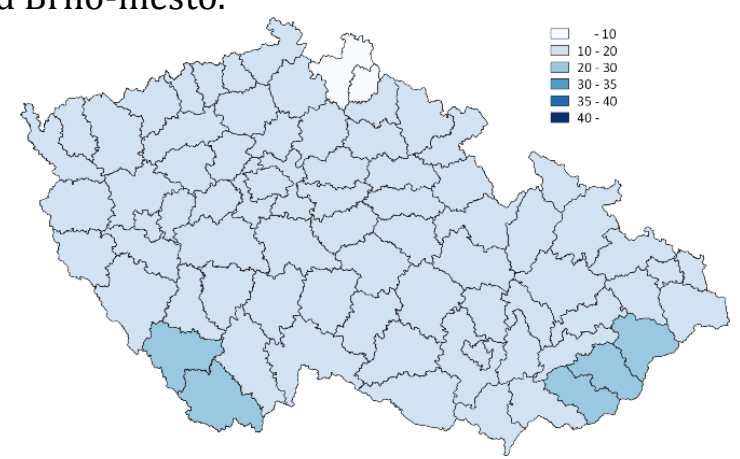

Figure 16. Geographical distribution of the crude birth rates, by districts, Czech lands, 1937 Sources: Author's calculations based on data from Austrian Statistics, CZSO and Historický GIS.

In the third phase of demographic transition, fertility started to decline gradually. It is essential to mention that at this stage, births were moderately high (Coale 1986; Diebolt and Perrin 2017). The first phase of decline started probably earlier than 1869, but just in a few districts. The fertility decline began when the crude birth rate dropped under 35 per thousand people (Chesnais 1992). In 1869, the crude birth rate was ranging from 35 to 40 and more per thousand people in most districts. In 1881 the situation did not change, but we can distinguish districts that entered the fertility decline stage, located in North Bohemia, including the city of Liberec, South Bohemia, Silesia, North Moravia. After the 1890s, about half of the districts entered the fertility decline stage. Districts were quite heterogeneous. A substantial reduction of 17\% in crude birth rate is reached between 1900 and 1910 . In only ten years, most districts moved to a modern regime of controlled fertility with a crude birth rate of 30 per thousand people or less. The last districts entering fertility decline were located in West-Northern Bohemia (partly), South-Eastern Moravia and Silesia (partly). The second phase of fertility decline started after 1921 . The change in crude birth rate accounted for $-22 \%$, one of the highest recorded levels until this point. Crude birth rate values dropped from 20 to 30 per thousand people to 10 to 20 per thousand people. The sharpest drop in the crude birth rate during the demographic transition occurred between 1930 and 1937, and it accounted for 26\%. Almost all districts reached a crude birth rate between 10 and 20 per thousand people, which means that the parity limitation of fertility was spread all over the Czech lands.

\section{Migration}

During the demographic transition, the population was not influenced only by natural processes but also by migration, specifically internal migration. Internal mobility was increasing due to the industrialization process. People tended to move from agricultural areas to the industrialized ones. In this section, we are analyzing the population movement in the Czech lands in the period18691910. We use estimations of the migration using the balance method.

In 1869 the average net migration rate was -2 per thousand people. Districts with high positive net migration rates were located in Northern and Central Bohemia and Eastern Moravia. Districts with high negative net migration rates were located in the Western, Southern, and Central Bohemia (around Prague) and Eastern and Southern Moravia. Districts with the highest positive net migration rate (over 10 per thousand people) were Prague, Prague-západ, Prague-východ, Most, Teplice and Ústí nad Labem. Districts with the highest negative net migration rate (over 10 per thousand people) were Rakovník, Beroun, Př́bram, and Havlíčkův Brod (figure 17). 


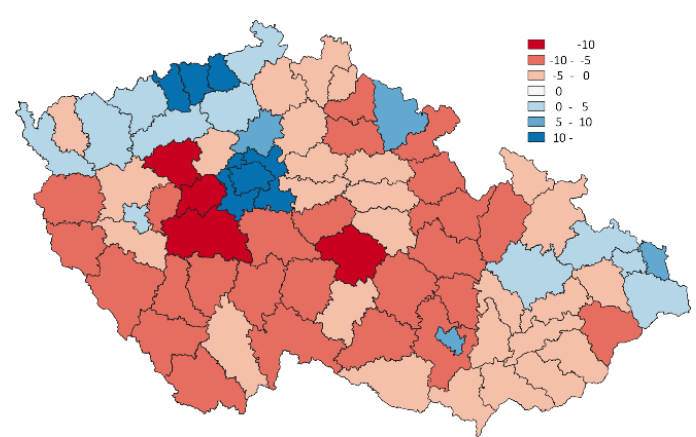

Figure 17. Geographical distribution of net migration rates, by districts, Czech lands, 1869 Sources: Author's calculations based on data from Austrian Statistics, CZSO and Historický GIS.

During the period 1869-1881, the migration did not change significantly. In 1881 the average net migration rate was -3 per thousand people. The districts with high positive net migration rates were located in Northern and Central Bohemia, and Eastern Moravia (figure 18), but a decrease was observed compared to 1869. The districts with high negative net migration rates were located in the Western, Southern, and Central Bohemia (around Prague), and Eastern and Southern Moravia. The districts with the highest positive net migration rate (over 10 per thousand people) are Most, Teplice, Ústí nad Labem, Jablonec nad Nisou, and Brno-město. The districts with the highest negative net migration rate (over 10 per thousand people) were Rakovník, Havlíčkưv Brod, Domažlice, Klatovy, Prachatice, Strakonice, and Písek.

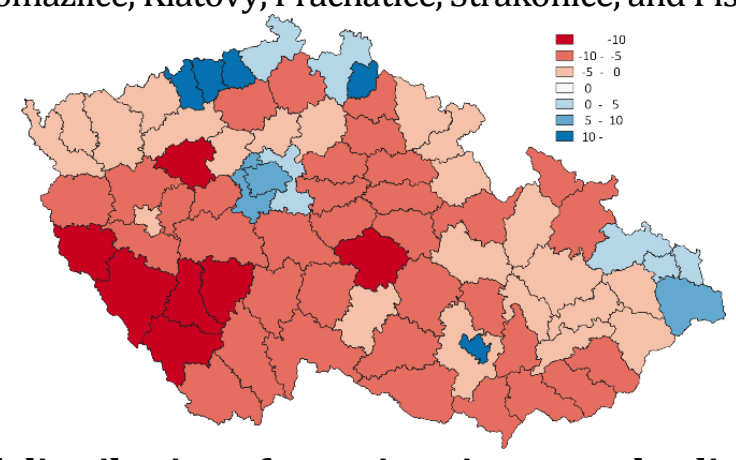

Figure 18. Geographical distribution of net migration rates, by districts, Czech lands, 1881 Sources: Author's calculations based on data from Austrian Statistics, CZSO and Historický GIS.

During the period 1881-1890, the migration continued to be constant. In 1890, the average net migration rate accounted for -3 per thousand people. Districts with high positive net migration rates were located in Northern and Central Bohemia and Eastern Moravia (figure 19) and Northern Silesia, but their amount decreased compared to 1881. Districts with high negative net migration rates were located in Western and Southern Bohemia and Eastern and Southern Moravia. The districts with the highest positive net migration rate (over 10 per thousand people) were Most, Teplice, Ústí and Labem and Karviná. Most, Teplice, Ústí nad Labem were among the districts with the highest positive net migration rate since 1869. The districts with the highest negative net migration rate (over 10 per thousand people) were Tachov, Domažlice, Klatovy, Prachatice, Strakonice, Havlíčkův Brod, Brno-venkov, and Bruntál.

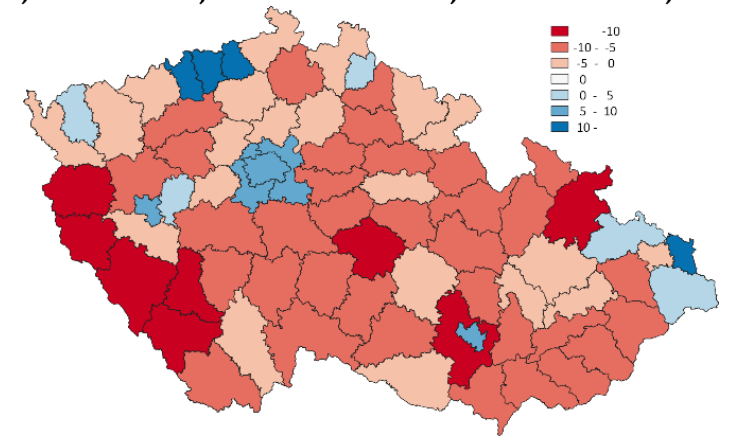

Figure 19. Geographical distribution of net migration rates, by districts, Czech lands, 1890 Sources: Author's calculations based on data from Austrian Statistics, CZSO and Historický GIS. 
During the period 1890-1900, we observe slight changes in the migration trends, although the average net migration rate remained constant at -3 per thousand people. The districts with a high positive net migration rate were mostly scattered in Northern and Central Bohemia (figure 20).

The districts with high negative net migration rate were located in Western and Southern Bohemia and Eastern and Northern Moravia and Silesia. The districts with the highest positive net migration rate (over 10 per thousand people) were Prague, Prague-západ, and Brno-město. The districts with the highest negative net migration rate (over 10 per thousand people) were Klatovy, Prachatice, Strakonice, Třebíč, Žd'ár nad Sázavou, Opava, and Karviná. Cities continue to grow, including suburban areas (e.g., Prague and Brno).

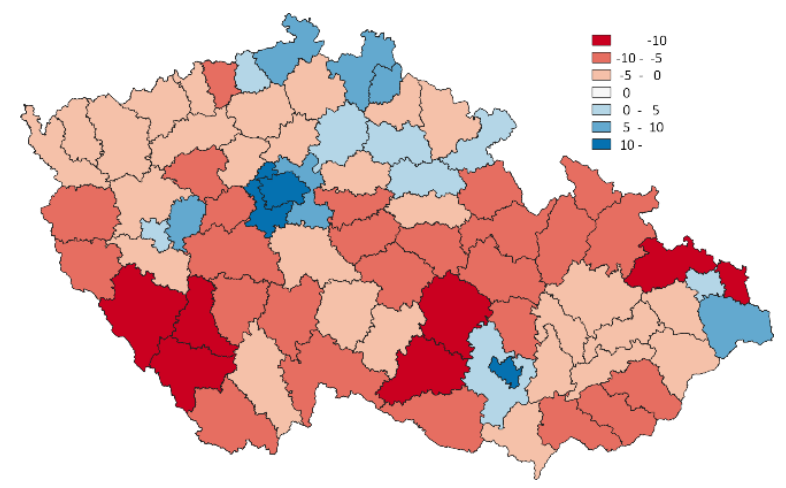

Figure 20. Geographical distribution of net migration rates, by districts, Czech lands, 1900 Sources: Author's calculations based on data from Austrian Statistics, CZSO and Historický GIS.

Figure 21 showed a slow change during 1900-1910. The average net migration rate was constant at -3 per thousand people. The districts with the highest positive migration rate also included Frýdek-Místek with a net migration rate of 17 per thousand people. Klatovy, Prachatice, Strakonice were among the districts with the highest negative net migration rate since 1881 . Cities and suburbs continued to grow.

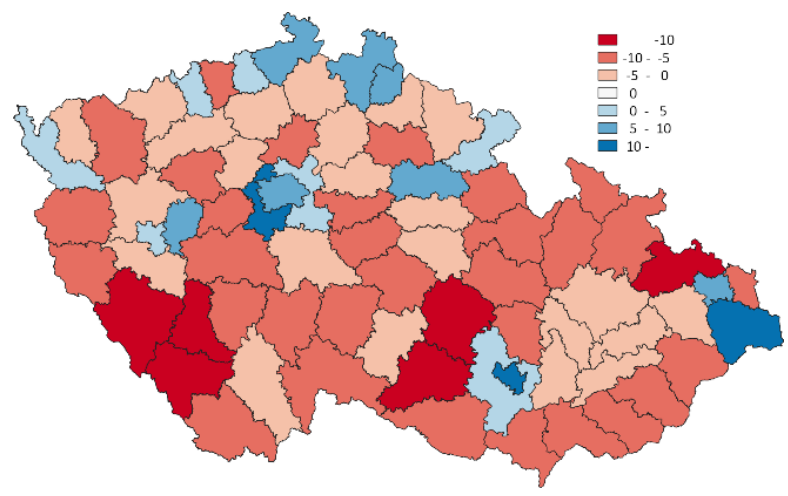

Figure 21. Geographical distribution of net migration rates, by districts, Czech lands, 1910 Sources: Author's calculations based on data from Austrian Statistics, CZSO and Historický GIS.

From 1869 to 1910 , migration slightly changed. The same areas consistently lost population or gained. For example, Klatovy, Prachatice, Strakonice lost population due to migration during the period 1881-1910. Most, Teplice, Ústí nad Labem gained population during the period 1869-1890. The districts with a high positive net migration rate were located mostly in Northern and Central Bohemia. The districts with high negative net migration rates were located in the Western, Southern, and Central Bohemia (surroundings of Prague) and Moravia (except Brno and surroundings of Brno). An essential trend during this period was the rural-urban migration. Cities always had positive net migration, and then the suburbs started to gain population due to migration from surrounding rural areas. 


\section{DISCUSSION AND CONCLUSIONS}

Similar levels of mortality and fertility characterize the pre-transition phase or first stage of demographic transition (Rowland 2003) in the Czech lands to other European countries. Both the crude death rates and crude birth rates were moderately high, as noted in prior studies (Notestein 1977; Coale 1986; Diebolt and Perrin 2017).

According to some research (e.g., Fialová, Pavlík and Vereš 1990), after 1820, crude birth rate declined due to an increase in the age at first marriage and the proportion of women never married, implying rather moderate-high levels of natality. From 1831-1847, the Czech lands were experiencing natural fertility (Henry 1961). CBR was fluctuating at around 40 per thousand people.

The next stage of the demographic transition is characterized by the mortality decline (Rowland 2003). The mortality varied during this period. It was generally higher in cities during industrialization. Cities were called demographic sinks (Dyson 2010). In rural areas, mortality was lower than the natality, this generating population growth, which through migration supported the urban growth (Dyson 2010; Bocquier and Costa 2015).

The third stage of demographic transition (Rowland 2003) starts with a fertility decline. The fall in fertility did not occur evenly but with vast differences between districts. Peripheral districts are usually more disconnected from the communication system and the capital, thus having a higher "behavioral" autonomy and are more prone to follow and respect cultural norms and traditions. This finding is supported by the example of France (Diebolt and Perrin 2017).

The migration section shows clear trends of rural-urban migration. The growth of cities between 1869 and 1910 was significant. Cities had constant population gain due to in-migration; this was a common phenomenon across all Europe (Davis 1955; Davis 1963; Knodel 1974). Urban areas were the most attractive destinations, but also a part of the North of Bohemia, which was more industrialized (migration from agrarian to industrialized districts) (Brabencova 1989; Barlow, Dostal and Hampl 1994). During the urbanization, the districts around the cities (suburbs) started to be a destination for in-migration too.

Nevertheless, at the national level, the net migration rate was preponderantly negative. A possible explanation is the emigration. Although industrialization decreased the proportion of the population involved in agriculture from $2 / 3$ to $1 / 3$ (1850-1910), the standards of living were poor. This led to high emigration, mostly among young people aged 20-29 (Fialová 1989).

In general, the demographic transition in the Czech Lands follows the pattern of European countries; the fertility declined shortly after the mortality decline. The demographic transition started in the Northern districts and Prague, this being related to the higher economic development in this region due to industrialization. At the regional level, we see vast differences in crude death rates and crude birth rates among the districts at the beginning of the demographic transition, and also some geographical patterns are observed in the trends, specifically between the industrialized Northern regions and the Eastern regions of the country. Still, at the end of demographic transition, the districts became almost homogeneous.

\section{REFERENCES}

1. ArcČR, ARCDATA PRAHA, ZÚ, ČSÚ. 2016. [citat 12 februarie 2020]. Disponibil: https://www.arcdata.cz/produkty/geograficka-data/arccr-500

2. AUSTRIAN STATISTICS. Austrian Library. 1869-1910. [citat 12 februarie 2020]. Disponibil: http://anno.onb.ac.at/

3. BECKER, G.S. A treatise on the family. Cambridge: Harvard University Press, 1981 [citat 12 februarie 2020]. Disponibil: https://brunofvieira.files.wordpress.com/2012/12/gary-becker-a-treatise-on-thefamily.pdf

4. BOCQUIER, P., COSTA, R. Which transition comes first? Urban and demographic transitions in Belgium and Sweden. In: Demographic Research. 2015, vol. 33, pp. 1297-1332 [citat 12 februarie 2020]. Disponibil: https://www.demographic-research.org/volumes/vol33/48/33-48.pdf

5. BRABENCOVÁ, J. On some problems of the migration of population and its age structures early in the $20^{\text {th }}$ century. In: Historická demografie. 1989, vol. 13, pp. 193-227. ISSN 0323-0937 [citat 21 martie 2020]. Disponibil: https://kramerius.lib.cas.cz/view/uuid:351ef543-4b25-11e1-1331001143e3f55c?page=uuid:351ef604-4b25-11e1-1331-001143e3f55c 
6. CALDWELL, J.C. Toward a restatement of demographic transition theory. In: Population and Development Review. 1976, vol. 2, no. 3/4, pp. 321-366 [citat 12 februarie 2020]. Disponibil: https://www.jstor.org/stable/1971615?seq=1

7. CHESNAIS, J-C. The demographic transition: Stages, patterns, and economic implications. Oxford: Oxford University Press, 1992. ISBN 9780198286592.

8. CLELAND, J., WILSON, C. Demand theories of the fertility transition: an iconoclastic view. In: Population Studies, 1987, vol. 41 (1), pp. 5-30. ISSN 0032-4728, ISSN 1477-4747.

9. COALE, A.J. Demographic effects of below-replacement fertility and their social implications. In: Population and Development Review. 1986, vol. 12, pp. 203-216. ISSN 0098-7921, elSSN 1728-4457.

10. COALE, A.J. The demographic transition. In: The Pakistan Development Review. 1984, vol. 23 (4), pp. 531-552 [citat 12 februarie 2020]. Disponibil: https://pubmed.ncbi.nlm.nih.gov/12280194/

11. CZECH STATISTICAL OFFICE. Statistical databank. 1921-1937. [citat 10 iunie 2018]. Disponibil: https://www.czso.cz/csu/czso/obyvatelstvo_lide

12. DAVIS, K. The origin and growth of urbanization in the world. In: American Journal of Sociology. 1955, vol. 60 (5), pp. $429-437$ [citat 23 februarie 2020]. Disponibil: http://hiebertglobalcenter.org/blog/wp-content/uploads/2013/04/Reading-9-Davis-The-Originand-Growth-of-Urbanization-in-the-World.pdf

13. DAVIS, K. The theory of change and response in demographic history. In: Population Index. 1963, vol. 29 (4), pp. 345-366 [citat 12 martie 2020]. Disponibil: https://www.ssc.wisc.edu/ walker/wp/wpcontent/uploads/2012/04/Davis1963.pdf

14. DEMENY, P. Early fertility decline in Austria-Hungary: a lesson in demographic transition. Daedalus. 1968, vol. 97 (2), pp. 502-522. ISSN 0011-5266, eISSN 1548-6192.

15. DIEBOLT, C., PERRIN, F. Understanding Demographic Transitions: An Overview of French Historical Statistics. Springer. 2017. 176 p. ISBN 978-3-319-83104-6 [citat 12 martie 2020]. Disponibil: https://www.springer.com/gp/book/9783319446509

16. DYSON, T. Population and development: the demographic transition. London-New York: Zed Books, 2010. 268 p. ISBN 978-1842779605.

17. FIALOVÁ, L. Age structure of the balance of migration in the Czech lands in 1870-1910. In: Historická demografie. 1989, vol. 13, pp. 229-234. ISSN 0323-0937 [citat 21 martie 2020]. Disponibil: https://kramerius.lib.cas.cz/view/uuid:351ef543-4b25-11e1-1331001143e3f55c?page=uuid:351ef604-4b25-11e1-1331-001143e3f55c

18. FIALOVÁ, L. Zmeny ve vyvoji plodnosti v ceskych zemich za demograficke revoluce. In: Historická demografie. 1991, vol. 15, pp. 143-189. [citat 21 martie 2020]. Disponibil: https://kramerius.lib.cas.cz/view/uuid:36380663-4b25-11e1-1331001143e3f55c?page=uuid:363806f2-4b25-11e1-1331-001143e3f55c

19. FIALOVÁ, L., PAVLÍK, Z., VEREŠ, P. Fertility decline in Czechoslovakia during the last two centuries. In: Population Studies. 1990, vol. 44 (1), pp. 89-106. ISSN 0032-4728, eISSN 1477-4747.

20. JÍCHOVÁ, J., SOUKUP, M. et al. Geodatabáze historických statistických a prostorových dat Prahy ze Sčíání lidu, domů a bytů 1921-2011 = Geodatabase of historical statistical and spatial data of Prague from the Population and Housing Census 1921-2011. Praha: Urbánní a regionální laboratoř, Př́rodovědecká fakulta Univerzity Karlovy v Praze, 2014.

21. HARPER, S. How population change will transform our world. Oxford: Oxford University Press, 2016. 160 p. ISBN 978-0198784098.

22. KIRK, D. Demographic transition theory. In: Population Studies. 1996, vol. 50 (3), pp. 361-387. ISSN 1477-4747.

23. KNODEL, J. The decline of fertility in Germany, 1871-1939. Princeton: Princeton University Press, 1974. 328 p. ISBN 9780691645377.

24. LEASURE, J.W. Factors involved in the decline of fertility in Spain 1900-1950. In: Population Studies. 1963, vol. 16 (3), pp. 271-285. ISSN 1477-4747.

25. LESTHAEGHE, R. A century of demographic and cultural change in Western Europe: An exploration of underlying dimensions. In: Population and Development Review. 1983, vol. 9 (3), pp. 411-435. ISSN 0098-7921, eISSN 1728-4457.

26. NOTESTEIN, F.W. Economic problems of population change. In: J. OVERBEEK (ed.). The evolution of 
population theory. Westport: Greenwood Press, 1977, pp. 139-152. ISBN 9780837193137.

27. OMRAN, A.R. The epidemiologic transition theory revisited thirty years later. In: World health statistics quarterly. 1998, vol. 51 (2-4), pp. 99-119 [citat 21 martie 2020]. Disponibil:

https://pdfs.semanticscholar.org/b833/1fd67628ec7364a045f39bc81305309f6f86.pdf?_ga=2.5442 4616.1074047851.1592307154-1892114140.1575623800

28. PAVLÍK, Z. Demografická revoluce jako globální zákonitost populačního vývoje = Demographic revolution as a global pattern of population development. Praha: Př́rodovědecká fakulta UK, 1977 [citat 21 martie 2020]. Disponibil: https://viaf.org/viaf/309488352/

29. PAVLÍK, Z. The theory of demographic revolution. In: European demographic information bulletin. 1980, vol. 11 (4), pp. 130-139. ISSN 0046-2756.

30. PAVLÍK, Z., KUČERA, T., HAMPL, M. Demographic transition and contemporary population development. In: M. BARLOW, P. DOSTÁL, M. HAMPL (eds). Territory, Society and Administration. The Czech Republic and the Industrial Region of Liberec. Amsterdam: Instituut voor Sociale Geografie, Universiteit van Amsterdam, 1994. ISBN 90-6993-087-0.

31. PAVLÍK, Z., RYCHTAŘÍKOVÁ, J. ŠUBRTOVÁ, A. Základy demografie. Praha: Academia, 1986. 732 p.

32. PRESTON, S.H. The changing relation between mortality and level of economic development. In: Population Studies. 1975, vol. 29 (2), pp. 231-248. ISSN 1477-4747.

33. REHER, D.S. The demographic transition revisited as a global process. In: Population, space and place. 2004, vol. 10 (1), pp. 19-41. ISSN 1544-8452.

34. RŮŽKOVÁ, J., ŠKRABAL, J. Historický lexikon obcí České republiky 1869-2005, Český statistický úřad, 2006.

35. ROWLAND, D.T. Demographic Methods and Concepts. New York: Oxford University Press, 2003. ISBN 978-0198752639.

36. SCHULTZ, T.W. Economics of the family; marriage, children, and human capital. Chicago: University of Chicago Press, $1974.593 \mathrm{p}$.

37. VISHNEVSKII, A.G. Demograficheskaia revoliutsiia [Demographic revolution]. M.: Statistika, 1976. $238 \mathrm{~s}$.

\section{ARTICLE HISTORY}

Received 08 June 2020

Accepted 17 June 2020 